забарвлення, динаміку звуку. Спілкування в умовах дистанційного навчання має й багато інших складнощів, однак маємо відмітити і позитивні моменти, які полягають у розкритті нових перспектив, стимулів розвитку мистецької освіти. Так, необхідність самостійно опрацьовувати великі об'єми навчального матеріалу стимулює розвиток навичок самоорганізації, ініціативності, відповідального ставлення учнів до занять, а педагоги отримують можливість проявити креативність у доборі експериментальних методів викладання своєї дисципліни, освоїти навички використання в практиці роботи сучасні інформаційно-комунікаційні технології.

Отже, сучасні реалії функціонування мистецької освіти викликали необхідність оволодіння педагогами новими фаховими уміннями та навичками, дозволили визначити недоліки технічного забезпечення навчального процесу, перевірити рівень підготовленості учнів до самостійних вправлянь, та визначити ефективні шляхи формування навичок самоорганізації процесу навчання учнів.

1. http://mon-covid19.info/

Список використаних джерел:

2. https://mon.gov.ua/ua/

DOI 10.36074/22.05.2020.v3.09

\title{
ПРОФЕСІЙНА УСПІШНІСТЬ МАЙБУТНЬОГО ВЧИТЕЛЯ
}

\author{
Євтух Микола Борисович \\ дійсний член (академік) НАПН України, доктор педагогічних наук, профресор \\ Інститут педагогіки НАПН України, Україна
}

Профресійна успішність вчителя часто оцінюється 3 точки зору його професійних досягнень як от: педагогічна майстерність, результативність успішності його учнів, методична та педагогічна компетентність тощо, i, меншою мірою, як особистісний показник досягнення вершин реалізації особистісних потенцій вчителя, самореалізації. Саме з появою акмеологічної педагогіки стало можливим звернути увагу на розвиток внутрішнього потенціалу особистості вчителя, який $є$ основою його професіоналізму та майстерності, складає основу професійного іміджу та сприяє кар'єрному зростанню.

Визначальними чинниками становлення професійної успішності за акмеологічного підходу можна визначити такі: здібності до педагогічної діяльності; профресійну компетентність; педагогічну мотивацію (свідомий умотивований вибір профресії); гуманістичну спрямованість (любов до дітей, повага, толерантність тощо); особистісні якості (чесність, справедливість, чемність, вимогливість, цілеспрямованість, працездатність, наполегливість тощо) та зовнішні чинники (безпечне освітнє середовище, співпраця і підтримка педагогічного колективу тощо).

У педагогічних наукових дослідженнях пропонують акмеологічні моделі сучасного педагога та рівні професійного зростання особистості. Акмеологічна модель педагога, розроблена Г. Даниловою, містить такі компоненти: компетентність (психолого-педагогічні й соціальні знання, теоретико-практичні й методичні знання, педагогічні вміння, педагогічні здібності); особистісну орієнтацію (самореалізацію у контексті акмеологічної моделі «Я - компетенція» в динаміці від «Я - реальний» до «Я - перспективний (ідеальний)»; морально-духовну культуру 
(моральну свідомість, моральну діяльність, моральні стосунки) [6, 6].

В. Максимова складовими акмеологічної моделі визначає профресійну, особистісну духовну зрілість та акмеологічну позицію педагога. Професійну зрілість автор визначає як готовність педагога до інноваційної професійнопедагогічної діяльності, структура якої передбачає професійну компетентність як систему знань і умінь педагога; педагогічну майстерність як здатність до творчого, нестандартного вирішення професійних завдань; педагогічну спрямованість професійної діяльності як систему домінуючих мотивів роботи у школі, стійку мотивацію педагогічної діяльності. Окреслені моделі є доволі близькими за своєю сутністю.

Профресійна акмеологія приділяє значну увагу визначенню та аналізу рівнів професійної діяльності та зрілості особистості фрахівця. У становленні професійності особистість проходить чотири етапи оволодіння професією: початковий рівень оволодіння професією (адаптація до неї, первинне засвоєння чинних норм, необхідних технологій тощо); рівень фрахової майстерності (використання у своїй діяльності кращих зразків професійного досвіду, оволодіння прийомами індивідуального та особистісно-орієнтованого підходу до суб'єктів взаємодії); рівень самоактуалізації в професії (усвідомлення можливостей професії для розвитку особистості, саморозвиток за допомогою професії) та найвищий рівень - рівень творчості фрахівця (особистісний творчий вклад, внесення авторських пропозицій щодо окремих завдань, прийомів, засобів, методів, фрорм організації процесу навчання, створення нових систем ефективної взаємодії). На цьому рівні особистість досягає професійної успішності, ії професіоналізм досягає вершин свого розвитку, а професійна діяльність перетворюється у творчу, рефлексивну та самодостатню.

На основі викладеного виокремимо основні компоненти акмеологічної моделі професійної успішності майбутнього педагога: установка на професійноособистісне зростання: когнітивно-емотивний компонент, емпатія, рефрлексія; здатність до самопізнання: самопрезентація, соціальне порівняння (власного досвіду та досвіду інших); актуалізація здатності до розвитку: саморегуляція, внутрішній самоконтроль (самомоніторинг, самоатрибуція), саморозвиток; здатність до самореалізації - самовираження, самопроектування, самопрезентація.

Становлення професійної успішності майбутнього вчителя відповідно до акмеологічної моделі успішності може здійснюватися за такими етапами:

І етап: підготовчий - фрормування мотиваційної сфери майбутнього вчителя установка на професійно-особистісне зростання;

II етап: діагностичний - розвиток здатності до самоусвідомлення та самопізнання майбутнім вчителем власних потреб та здатностей;

III етап: розвиваючий - актуалізація здатності до розвитку і саморозвитку, володіння емоціями, саморегуляції внутрішнього стану;

IV етап: розвиток здатності до самовираження, самопроектування, само менеджменту та самопрезентації.

Акмеологічна модель становлення професійної успішності вчителя можлива за умови застосування акметехнологій, які передбачають розвиток когнітивного та емотивного компонентів структури особистості, забезпечують здатність до особистісного зростання в педагогічній діяльності та самореалізації в різних сфрерах профресійної взаємодії.

Список використаних джерел:

1. Данилова Г.С. (2003). Акмеологічна модель педагога у XXI столітті. Рідна школа, (6). (6-9). 